\title{
A Study of Chemical, Mineral Compositions (of Some Metals) and Natural Radioactivity in Porcelain and Ceramic Dinner Ware
}

\author{
Safia H. Q. Hamidalddin \\ Physics Department, Faculty of Science, Jeddah University, Jeddah, Saudi Arabia \\ Email: Safiahqh@yahoo.com
}

How to cite this paper: Hamidalddin, S. H. Q. (2020). A Study of Chemical, Mineral Compositions (of Some Metals) and Natural Radioactivity in Porcelain and Ceramic Dinner Ware. Journal of Geoscience and Environment Protection, 8, 209-221. https://doi.org/10.4236/gep.2020.811014

Received: October 22, 2020

Accepted: November 24, 2020

Published: November 27, 2020

Copyright ( 2020 by author(s) and Scientific Research Publishing Inc. This work is licensed under the Creative Commons Attribution International License (CC BY 4.0).

http://creativecommons.org/licenses/by/4.0/

\begin{abstract}
Fifteen Porcelain and Ceramic Dinner Wares samples (collected from local commercial suppliers-Jeddah Saudi Arabia) were studied applying X-Ray Diffraction and Atomic Absorption techniques were used to study the Chemical, Mineral, Compositions Concentrations (of Some Metals). In addition, the Natural Radioactivity measurements of ${ }^{226} \mathrm{Ra},{ }^{232} \mathrm{Th}$ and ${ }^{40} \mathrm{~K}$, was used by a high-purity germanium (HPGe) detector. X-ray diffraction results showed that the major mineral constituents of 15 samples were quartz $\left(\mathrm{SiO}_{2}\right)$ (except one), minor and trace elements vary from sample to sample. Atomic absorption spectroscopy results of the concentrations for ( $\mathrm{Al}, \mathrm{Pb}, \mathrm{Bi}, \mathrm{U}$, Th and $\mathrm{K}$ ) in (ppm) showed that $\mathrm{Al}_{2} \mathrm{O}$ average was 10.3 (ppm) (10\%) less than the acceptable value. $\mathrm{PbO}$, its average was $1.65 \mathrm{ppm}$ which was slightly greater than the allowed value $1.35 \mathrm{ppm}$. Bi concentrations for all samples were lower than $(\mathrm{DL}<10)$. For most samples $\mathrm{U}$, concentrations were lower than $(\mathrm{DL}<5)$ except samples $\mathrm{C} 9$ and $\mathrm{C} 11$. Th concentrations ranged from LDL ( $<1$ to 52.88) and were much greater than the acceptable value 7.24 ppm except samples P1, $\mathrm{P} 2, \mathrm{P} 4$. The potassium concentration average was greater than the acceptable value. The average concentrations of ${ }^{238} \mathrm{U},{ }^{232} \mathrm{Th}$ and ${ }^{40} \mathrm{~K}$ were $(83.83,91.05$ and 751.07$) \mathrm{Bq} / \mathrm{kg}$ dry. The radium equivalent activity concentration $R a_{e q}$ $(\mathrm{Bq} / \mathrm{kg})(302.61)$ was less than recommended value (370), gamma dose rate $D$ (nGy/h) average (140.15) was much higher than the recommended value (60) (UNSCEER). $D_{\text {eff }}$ (mSv/year) and $H_{i x}$ were below the published admissible limit $\leq 1$ and the risk is negligible. This study offers needed information for consumers at exposure risk and is useful to be found in terms of radiation protection.
\end{abstract}

\section{Keywords}

X-Ray Diffraction, Atomic Absorption, Gamma-Ray Spectroscopy, Natural 
Radioactivity, Dinnerware

\section{Introduction}

Ceramics are one of the most important types of the industrial materials. Ceramic is made of a mixture of clay, feldspar, silica, talc kaolin minerals together with zirconium silicates $\left(\mathrm{ZrSiO}_{4}\right)$. The ceramic raw materials contain naturally occurring radionuclide ${ }^{238} \mathrm{U}$ and, ${ }^{232} \mathrm{Th}$ series, and ${ }^{40} \mathrm{~K}$ (Abbady, 2004). Ceramic causes a potential radiation risk due to these radiation exposures and their chemical composition, controls should be restricted (Almayahi et al., 2012). Measurements of the radio activities from houseware, due to their composition contain radionuclides of ${ }^{238} \mathrm{U},{ }^{232} \mathrm{Th}$ and ${ }^{40} \mathrm{~K}$ and their radioactive series are important. Such activities would provide the useful data of doses and hazard indices to make them safe in houseware product (Ahmad et al., 2015; Papadopoulos et al., 2013). There are many numbers of work worldwide measured the natural radioactivity of ceramic and porcelain by gamma rays spectroscopy and used their values to determine the doses and the hazard indices, these data are important to human health and compare the results with the recommended limits (Aksoy et al., 2010; Tufail et al., 2010; Janković et al., 2013). The objectives of this study are: 1) Use X-Ray Diffraction and Atomic Absorption techniques to study the Chemical, Mineral, Compositions and Concentrations (of Some Metals) in fifteen local and imported Ceramic and Porcelain dinner wares samples. 2) Measure the Natural Radioactivity of ${ }^{226} \mathrm{Ra},{ }^{232} \mathrm{Th}$ and ${ }^{40} \mathrm{~K}$ by gamma-ray spectroscopy having a high-purity germanium (HPGe) detector in these samples, and to determine their specific radioactivity concentrations. 3) Calculate the radium equivalent activity concentrations $R a_{e q}(\mathrm{~Bq} / \mathrm{kg})$, gamma dose rate $D$ (nGy/h), annual effective dose $D_{\text {eff }}\left(\mathrm{mSv} /\right.$ year) and external hazard $H_{i x}$ values, and compare the results with worldwide values to control the causes of potential radiation risk.

\section{Materials and Methods}

\subsection{Sample Collection and Preparation}

Fifteen different types and different origins of food wares were collected from commercial suppliers as shown in Table 1. These samples were crushed, grounded, sieved by $1 \mathrm{~mm} \times 1 \mathrm{~mm}$, and dried to $105^{\circ} \mathrm{C}$ for $24 \mathrm{hr}$. not to lose the volatile ${ }^{137} \mathrm{Cs}$ or the natural polonium and to remove moisture. Twenty gm of the dried samples were kept for analyzed by XRD and Atomic Absorption spectroscopy. For radiometric analysis, each dried sample was weighed and transferred to $640 \mathrm{cc}$ poly-ethylene Marinelli beakers then sealed and stored for 2 - 4 months to stop the escape of Radon gas and to get the radioactive secular equilibrium between ${ }^{238} \mathrm{U},{ }^{232} \mathrm{Th}$ and their progenies. 
Table 1. Origin, type, and description of the 15 samples.

\begin{tabular}{cccc}
\hline Sample Code & origin & type & Description \\
\hline P1 & China & Porcelain cup & White glazed \\
P2 & France & Porcelain cup & White glazed \\
P3 & Turkey & Porcelain cup & White glazed \\
P4 & England & Porcelain plate & White glazed \\
P5 & China & Porcelain plate & White glazed \\
P6 & Vietnam & Porcelain plate & White glazed \\
P7 & Portugal & Porcelain plate & White glazed \\
C8 & Pakistan & ceramic cup & Color glazed \\
C9 & S. Yemen Hadramout & ceramic pot & Color glazed \\
C10 & Saudi Arabia Makkah & ceramic cup & Color glazed edge \\
C11 & Morocco & ceramic pot & Color glazed \\
C12 & IRAN & ceramic pot & Color glazed-edge \\
C13 & Yemen Saada & ceramic plate & Color glazed \\
C14 & Saudi Arabia Rasiefa & ceramic plate & Color glazed \\
C15 & Saudi Arabia Jiad & ceramic plate & Color glazed \\
\hline
\end{tabular}

\subsection{Experimental Techniques}

Ten gm of the dried samples were analyzed by XRD spectrometer model Burker XR-D D8 Advance for the chemical and mineral compositions. Ten gm of the samples were used for the analysis by Atomic Absorption spectrometer model OPTIMA 4000 DV Series Perkin Elmer for the Al, Bi, Pb, U, Th, and K concentrations. The samples were analyzed non-destructively, using gamma-ray spectrometry with Canberra high purity germanium (HPGe) coaxial detector with relative efficiency of $25 \%$ and FWHM $2.0 \mathrm{keV}$ at $1332 \mathrm{keV}$, of ${ }^{60} \mathrm{Co}$. Genie 2000 basic spectroscopic software was installed in the computer for data acquisition and analysis. The system was calibrated for energy using standard gamma-ray sources and absolute efficiency. The lowest detection limits (DL) of HPGe detector system were $0.33,0.27$, and 2.31 for ${ }^{226} \mathrm{Ra},{ }^{232} \mathrm{Th}$, and ${ }^{40} \mathrm{~K}$ respectively for a counting time of 82,800 seconds. An empty polyethylene Marinelli beaker was placed in the detection system for this time period in order to collect the background count rates. Then, each sample was measured during a same accumulating time.

\subsection{Calculation}

The concentrations of ${ }^{226} \mathrm{Ra},{ }^{232} \mathrm{Th}-232$ and ${ }^{40} \mathrm{~K}$ were determined from the average concentrations of gamma ray lines of energies tabulated in Table 2. There is secular equilibrium between the ${ }^{226} \mathrm{Ra}$ and its daughters ${ }^{214} \mathrm{~Pb},{ }^{214} \mathrm{Bi}$. For ${ }^{232} \mathrm{Th}$, the secular equilibrium is between the ${ }^{232} \mathrm{Th}$ and its daughters ${ }^{228} \mathrm{Ac},{ }^{212} \mathrm{Bi}$ and ${ }^{208} \mathrm{Tl}$. The concentration of ${ }^{40} \mathrm{~K}$ is determined. 
Table 2. Gamma lines used for spectrometry determinations.

\begin{tabular}{cccc}
\hline Radionuclide & Daughter Nuclei & $\mathrm{E}(\mathrm{KeV})$ & Photon Disintegration \% \\
\hline${ }^{226} \mathrm{Ra}$ & ${ }^{214} \mathrm{~Pb}$ & 295.09 & 20 \\
& & 351.87 & 38 \\
& & 609.31 & 49 \\
& ${ }^{214} \mathrm{Bi}$ & 1120.27 & 16 \\
& & 1764.49 & 16 \\
${ }^{232} \mathrm{Th}$ & 338.32 & 13 \\
& ${ }^{228} \mathrm{Ac}$ & 911.16 & 30 \\
& & 968.97 & 18 \\
& ${ }^{212} \mathrm{Bi}$ & 727.25 & 33 \\
${ }^{208} \mathrm{Tl}$ & $583.10-2614.48$ & 36 \\
& & & 11 \\
\hline
\end{tabular}

Determination of activity concentrations in $\mathrm{Bq} / \mathrm{kg}$ dry weight was calculated using the equation (Younis et al., 2018):

$$
A_{c}(\mathrm{~Bq} / \mathrm{kg})=N_{c} / m
$$

where: $N_{c}$ is the net count area of the gamma line for the measured sample (counts/second), $m$ is mass of the sample, $\epsilon$ is the absolute efficiency of the spectrometer at the photo-peak energy and $\beta$ is the probability of emission of the gamma ray. Exposure to radiation has been defined in terms of the radium equivalent $R a_{e q} \mathrm{~Bq} / \mathrm{kg}$ which is calculated from equation (UNSCEAR, 1993).

$$
R a_{e q}=C_{R a}+\left(C_{T h} \times 1.43\right)+\left(C_{K} \times 0.077\right)
$$

where: $C_{R a}, C_{T h}$ and $C_{K}$ are the concentrations in $\mathrm{Bq} / \mathrm{kg}$ dry weight for radium, thorium and potassium respectively. The total air absorbed dose rate $(\mathrm{nGy} / \mathrm{h})$ in the outdoor air at $1 \mathrm{~m}$ above the ground due to the activity concentrations of ${ }^{226} \mathrm{Ra},{ }^{232} \mathrm{Th}$ and ${ }^{40} \mathrm{~K}(\mathrm{~Bq} / \mathrm{kg})$ dry weight was calculated using the equation (UNSCEAR, 2000; Veiga et al., 2006).

$$
D(\mathrm{nGy} / \mathrm{h})=0.427 C_{R a}+0.623 C_{T h}+0.043 C_{K}
$$

where: $C_{R a}, C_{T h}$, and $C_{K}$ are the specific activities (concentrations) of ${ }^{226} \mathrm{Ra},{ }^{232} \mathrm{Th}$ and ${ }^{40} \mathrm{~K}$ in $\mathrm{Bq} / \mathrm{kg}$ dry weight respectively. The annual effective dose equivalent $D_{\text {eff }}(\mathrm{mSv} / \mathrm{y})$ in air was calculated using the values of the absorbed dose rate by applying the dose conversion factor of $0.7 \mathrm{~Sv} / \mathrm{Gy}$ and the outdoor occupancy factor of 0.2 (people spend about $20 \%$ of their life outdoor) the Annual Effective Dose (in $\mathrm{mSv} / \mathrm{y}$ ) received by population can be calculated using equation (UNSCEAR, 2000):

$$
D_{\text {eff }}(\mathrm{mSv} / \mathrm{y})=D(\mathrm{nGy} / \mathrm{h}) \times 8766 \mathrm{~h} \times 0.7(\mathrm{~Sv} / \mathrm{Gy}) \times 0.2 \times 10^{-6}
$$

where: $D(\mathrm{nG} / \mathrm{h})$ is the total air absorbed dose rate in the outdoor. $8766 \mathrm{~h}$ is the number of hours in 1 year. $10^{-6}$ is conversion factor of nano and milli. To limit the annual external gamma-ray dose to $1.5 \mathrm{~Gy}$ for the samples under investiga- 
tion, the external hazard index $\left(H_{e x}\right)$ is given by the equation (El Aassy Ibrahim et al., 2011):

$$
H_{e x}=C_{R a} / 370+C_{T h} / 259+C_{K} / 4810 .
$$

\section{Results and Discussion}

\subsection{XRD Analysis}

$\mathrm{X}$-ray diffraction is a non-destructive analytical technique, which provides detailed information about the atomic structure of crystalline substances, chemical composition, and physical properties of materials. It is a powerful tool in the identification of minerals in rocks and soils (Harris \& White, 2008). The minerals of 15 samples analyzed by XRD spectrometer are shown in Table 2 . The results show that the major mineral constituent of all samples (except $\mathrm{P} 4$ ) is quartz $\left(\mathrm{SiO}_{2}\right)$. As expected, most common type of clay (ceramic products are clay-based) consists of kaolinite, mica, quartz $\left(\mathrm{SiO}_{2}\right)$, and feldspar (a group of rock-forming tectosilicate minerals). While Porcelain is mostly kaolinite $\left(\mathrm{Al}_{2} \mathrm{Si}_{2} \mathrm{O}_{5}(\mathrm{OH})_{4}\right)$ and is defined as glazed or unglazed glassy ceramic. Minor element in porcelain samples is mullite $\left(\mathrm{Al}_{6} \mathrm{Si}_{2} \mathrm{O}_{13}\right)$ except sample 7 , its minor element is Albite $\left(\mathrm{NaAlSi}_{3} \mathrm{O}_{8}\right)$. In ceramic samples minor elements vary from sample to sample as well as trace elements in all samples. Table 3 represents the mineral chemical composition and its description (Don Leet et al., 1982).

Table 3. The mineral constituents analyzed by XRD spec.

\begin{tabular}{|c|c|c|c|}
\hline Sa. No. & MAJOR & MINOR & TRACE \\
\hline $\mathrm{P} 1$ & Quartz & Mullite & Albite, Zircon, Montmorillonite \\
\hline $\mathrm{P} 2$ & Quartz & Mullite & Albite, Zircon, Montmorillonite \\
\hline P3 & Quartz & Mullite & Albite, anasseite, Pargasite, Zircon, Zaherite \\
\hline $\mathrm{P} 4$ & Fluorite & - & - \\
\hline P5 & Quartz & Mullite & - \\
\hline P6 & Quartz & Mullite & - \\
\hline P7 & Quartz & Albite & Mullite, Artroeite \\
\hline $\mathrm{C} 8$ & Quartz & Muscovite & Mullite \\
\hline C9 & $\begin{array}{l}\text { Albite } \\
\text { Quartz }\end{array}$ & $\begin{array}{l}\text { Diopside, } \\
\text { Microcline }\end{array}$ & Nontronite, Saponite, Montmorillonite \\
\hline $\mathrm{C} 10$ & Quartz & Albite & $\begin{array}{l}\text { Pargasite, Calcite, Montmorillonite, } \\
\text { Nontronite, Clinechlore, Zircon, Kaolinite }\end{array}$ \\
\hline $\mathrm{C} 11$ & $\begin{array}{c}\text { Albite } \\
\text { Augite Quartz }\end{array}$ & Magnetite & Biotite, Saponite, Clinechlore, Kaolinite \\
\hline $\mathrm{C} 12$ & Quartz & Anatase & $\begin{array}{c}\text { Ablite, Diopside, Calcite, Ferroactinolite, } \\
\text { Gypsum, Nontronite, Zircon }\end{array}$ \\
\hline $\mathrm{C} 13$ & Albite Quartz & - & $\begin{array}{l}\text { Biotite, Magnetite, Clinechlore, } \\
\text { Kaolinite, Montmorillonite, Riebeckite }\end{array}$ \\
\hline $\mathrm{C} 14$ & Quartz & $\begin{array}{l}\text { Albite, } \\
\text { Microcline }\end{array}$ & $\begin{array}{l}\text { Calcite, Kaolinite, } \\
\text { Clinochloe Montmorillonite, Pargasite, zircon }\end{array}$ \\
\hline C15 & Quartz & $\begin{array}{l}\text { Albite, } \\
\text { Anatase }\end{array}$ & $\begin{array}{l}\text { Augite, Biotite, Magnetite, } \\
\text { Pargasite, Montmorillonite, }\end{array}$ \\
\hline
\end{tabular}




\subsection{Atomic Absorption Spectroscopy}

Table 4 lists the results of the concentrations for 15 porcelain and ceramic samples for sex elements ( $\mathrm{Al} . \mathrm{Pb}, \mathrm{Bi}, \mathrm{U}, \mathrm{Th}, \mathrm{K})$ are measured by atomic absorption spectroscopy. Ceramic and porcelain include Aluminum (Al) in the form of aluminum oxide $\left(\mathrm{Al}_{2} \mathrm{O}_{3}\right)$, Aluminum is considered to be a non-essential element and is known to be toxic to different species, the toxicity depends on its form in solution. Results show that the concentrations ( $\mathrm{ppm}$ ) of $\mathrm{Al}$ ranged from 4.56 (P2) to 15.97 (C10), with mean 10.3 (ppm) (10\%) which is less than the acceptable value (11\%) (Lehman, 2002). Lead (lead oxide (PbO)) glazes used on many kind of porcelain and ceramic food wares. Lead is high toxicity element when absorbed into the body, depending on the size and shape of the wares. It is harmful to human health at high concentrations, the allowed limit is $0.2 \mathrm{ppm}$ (European Community, EC, 2005). Lead concentration mean value is $1.65 \mathrm{ppm}$. Bi concentrations for all samples were lower than $(\mathrm{DL}<10)$. For $\mathrm{U}$, concentrations were lower than $(\mathrm{DL}<5)$ except samples $\mathrm{C} 9$ and $\mathrm{C} 11$ (7.67 and 11.84) respectively, these values are much less than values measured by gamma spectroscopy (C9: 93.8, C11: 144.8). Thorium is found almost everywhere, and it can be absorbed through food, drinking water, and in air. Thorium has no known biological function. Th concentrations ranged from LDL $(<1)(\mathrm{P} 2)$ to

Table 4. Concentrations of $\mathrm{Al}, \mathrm{Bi}, \mathrm{Pb}, \mathrm{U}$, Th and $\mathrm{K}$ measured by Atomic Absorption spectrometer.

\begin{tabular}{|c|c|c|c|c|c|c|c|c|c|}
\hline Elements & $\mathrm{Al}$ & $\mathrm{Pb}$ & $\mathrm{Bi}$ & & J & & & $\mathrm{r}$ & \\
\hline DL. & 1.00 & 1.00 & 10.00 & 5.00 & 61.75 & 1.00 & 4.07 & 1.00 & 0.031 \\
\hline Units & ppm & ppm & $\mathrm{ppm}$ & $\mathrm{ppm}$ & $\mathrm{Bq} / \mathrm{Kg}$ & $\mathrm{ppm}$ & $\mathrm{Bq} / \mathrm{Kg}$ & ppm & $\mathrm{Bq} / \mathrm{Kg}$ \\
\hline P1 & 12.26 & 1.07 & $<10$ & $<5$ & $<61.75$ & 6.71 & 27.31 & 2079.09 & 64.45 \\
\hline $\mathrm{P} 2$ & 4.56 & 1.64 & $<10$ & $<5$ & $<61.75$ & $<1$ & $<4.07$ & $28,868.00$ & 894.91 \\
\hline P3 & 13.31 & 2.23 & $<10$ & $<5$ & $<61.75$ & 52.88 & 219.01 & $55,139.70$ & 1709.33 \\
\hline P4 & 5.97 & 1.78 & $<10$ & $<5$ & $<61.75$ & 4.68 & 19.37 & $46,402.02$ & 1438.46 \\
\hline P5 & 10.96 & 2.44 & $<10$ & $<5$ & $<61.75$ & 33 & 136.67 & $48,205.50$ & 1494.37 \\
\hline P6 & 10.96 & 1.92 & $<10$ & $<5$ & $<61.75$ & 40.04 & 165.81 & $38,304.50$ & 1187.44 \\
\hline P7 & 10.78 & 1.11 & $<10$ & $<5$ & $<61.75$ & 25.04 & 103.70 & $21,165.00$ & 656.12 \\
\hline $\mathrm{C} 8$ & 9.83 & 2.38 & $<10$ & $<5$ & $<61.75$ & 45.72 & 189.34 & $32,220.00$ & 998.82 \\
\hline $\mathrm{C} 9$ & 9.14 & 1.76 & $<10$ & 7.76 & 93.8 & 17.56 & 72.73 & $27,929.90$ & 865.83 \\
\hline $\mathrm{C} 10$ & 15.97 & 1.68 & $<10$ & $<5$ & $<61.75$ & 47.96 & 198.62 & $15,771.00$ & 488.90 \\
\hline $\mathrm{C} 11$ & 9.18 & 1.80 & $<10$ & 11.84 & 144.80 & 15.84 & 65.61 & 4203.00 & 1303.33 \\
\hline $\mathrm{C} 12$ & 15.32 & 1.29 & $<10$ & $<5$ & $<61.75$ & 24.84 & 102.89 & 4774.00 & 147.99 \\
\hline $\mathrm{C} 13$ & 9.12 & 1.83 & $<10$ & $<5$ & $<61.75$ & 16.48 & 68.25 & $39,440.00$ & 1222.64 \\
\hline $\mathrm{C} 14$ & 14.51 & 1.75 & $<10$ & $<5$ & $<61.75$ & 41.36 & 171.27 & $18,936.00$ & 587.02 \\
\hline $\mathrm{C} 15$ & 14.32 & 1.75 & $<10$ & $<5$ & $<61.75$ & 35.28 & 146.11 & $16,155.00$ & 500.81 \\
\hline mean & 10.39 & 1.65 & & 9.8 & 119.31 & 27.16 & 114.54 & $24,974.54$ & 847.52 \\
\hline
\end{tabular}


$52.88 \mathrm{ppm}$ (P3), Th concentrations for all samples (accept P1, P2, P4) were much greater than the acceptable value 7.24 ppm (Rudnick et al., 2004). Potassium is the eighth most abundant element in the Earth's crust (2.1\%) (Emsley, 2001), it is found in almost all solids on Earth It is not found in pure form in nature, but in from of compounds. Potassium is an essential element for all organisms. Potassium toxicity, a condition called hyperkalemia, is very rare the potassium concentrations in ppm range from 2079.09 (P1) to 48205.50 (P5), where the mean is $24974.54 \mathrm{ppm}(2.5 \%)$, which is greater than the acceptable value (1.92\%) (Heiserman, 1992).

Figure 1 shows a comparison between samples activity concentration values for ${ }^{232} \mathrm{Th}$, and ${ }^{40} \mathrm{~K}$ were measured by Gamma-Ray Spectrometry and samples concentration values for $\mathrm{Th}$, and $\mathrm{K}$ measured by Atomic Absorption Spectrometer. Both analysis results are in a good agreement and this means that the geochemical analysis (Atomic Absorption Spectrometer) can determine the concentrations of elements in the minerals with reasonable values.

\subsection{Gamma Spectroscopy}

Porcelain and ceramic samples were measured using the gamma spectrometer. The results in Table 6 show that: There is secular equilibrium between the ${ }^{226} \mathrm{Ra}$ and its daughters ${ }^{214} \mathrm{~Pb}$, their activities were used to calculate the concentrations of ${ }^{226} \mathrm{Ra}$ in $\mathrm{Bq} / \mathrm{kg}$ dry weight. Their ranged were from 11.51 (P2) to 192.67 (P7). Samples show high radium in samples P3 (184.68) and P7 (192.67). The decay of short half-life daughters ${ }^{228} \mathrm{Ac},{ }^{212} \mathrm{Bi}$, and ${ }^{208} \mathrm{Tl}$ were used to determine the activity concentrations of ${ }^{232} \mathrm{Th}$, since there is secular radioactivity equilibrium in ${ }^{232} \mathrm{Th}$ series. The activity concentrations in Bq/.kg dry weight of ${ }^{232} \mathrm{Th}$ were varied form 13.01 (P4) to 184.04 (C10). Activity concentration values in Bq/.kg dry weight for ${ }^{40} \mathrm{~K}$ were from low value 67.10 (P1) to high value 1736.30 (P3). The ${ }^{226} \mathrm{Ra}$, ${ }^{232} \mathrm{Th}$ and ${ }^{40} \mathrm{~K}$ activity concentrations were varied, this is due to the mineral constituents (Table 3), of the studied samples. The high value of ${ }^{226} \mathrm{Ra}$ was in porcelain sample (P7), ${ }^{232} \mathrm{Th}$ highest concentration was in ceramic sample (C10), for ${ }^{40} \mathrm{~K}$, the highest concentration was in porcelain sample (P3), this is due to the chemical composition of these sample (Table 5).

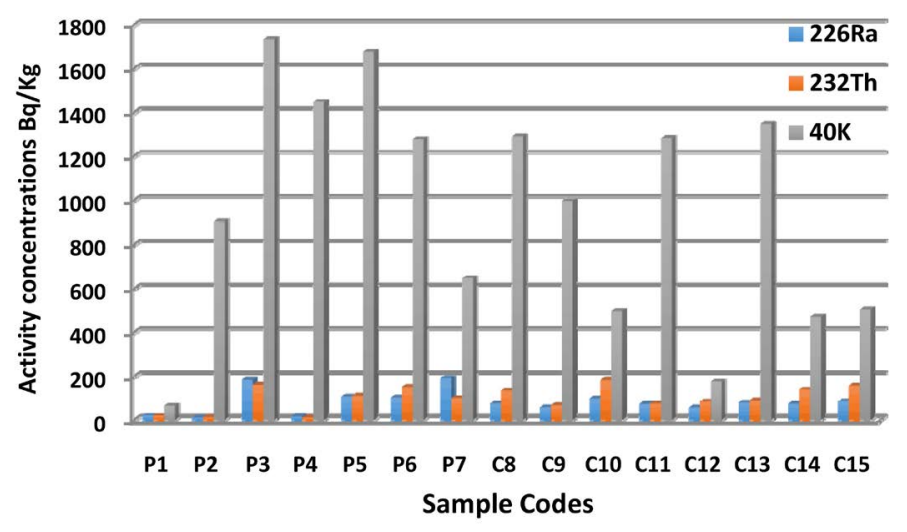

Figure 1. Activity concentrations $(\mathrm{Bq} / \mathrm{Kg})$ of ${ }^{226} \mathrm{Ra},{ }^{232} \mathrm{Th}$ and ${ }^{40} \mathrm{~K}$. 
Table 5. The mineral chemical composition and its description (Don Leet et al., 1982; Mineral Data, 2012).

\begin{tabular}{|c|c|c|c|}
\hline $\begin{array}{c}\text { Mineral } \\
\text { chemical composition }\end{array}$ & Description & $\begin{array}{l}\text { Mineral/chemical } \\
\text { composition }\end{array}$ & Description \\
\hline $\begin{array}{l}\text { Albite } \\
\mathrm{NaAlSi}_{3} \mathrm{O}_{8}\end{array}$ & $\begin{array}{l}\text { Sodium Plagioclase feldspar. } \\
\text { Magmatic and pegmatitic rocks. }\end{array}$ & $\begin{array}{l}\text { Manasseite } \\
\mathrm{Mg}_{6} \mathrm{Al}_{2}\left(\mathrm{CO}_{3}\right)(\mathrm{OH})_{16} \cdot 4\left(\mathrm{H}_{2} \mathrm{O}\right)\end{array}$ & In iron ore skarns. \\
\hline $\begin{array}{l}\text { Anatase } \\
\mathrm{TiO}_{2}\end{array}$ & $\begin{array}{l}\text { Derived from other Ti-bearing } \\
\text { minerals. Common as a } \\
\text { detrital mineral }\end{array}$ & $\begin{array}{l}\text { Microcline } \\
\mathrm{KAlSi}_{3} \mathrm{O}_{8}\end{array}$ & $\begin{array}{l}\text { Granitic gmatites } \\
\text { hydrothermal and, } \\
\text { metamorphic rocks. }\end{array}$ \\
\hline $\begin{array}{l}\text { Artroeite } \\
\mathrm{PbAlF}_{3}(\mathrm{OH})_{2}\end{array}$ & In a quartz-lined vug & $\begin{array}{l}\text { Montmorillonite } \\
\mathrm{NaCaAl}_{2} \mathrm{Si}_{4} \mathrm{O}_{10}(\mathrm{OH})_{2}\left(\mathrm{H}_{2} \mathrm{O}\right)_{10}\end{array}$ & $\begin{array}{l}\text { Absorbing water and } \\
\text { expanding. }\end{array}$ \\
\hline $\begin{array}{l}\text { Augite-a pyroxene } \\
(\mathrm{Ca}, \mathrm{Na})(\mathrm{Mg}, \mathrm{Fe}, \mathrm{Al}, \mathrm{Ti})(\mathrm{Si}, \mathrm{Al})_{2} \mathrm{O}_{6}\end{array}$ & $\begin{array}{l}\text { Ferromagnesian silicate. Basic } \\
\text { igneous and metamorphic rocks. }\end{array}$ & $\begin{array}{l}\text { Mullite } \\
\mathrm{Al}_{6} \mathrm{Si}_{2} \mathrm{O}_{13}\end{array}$ & Remelted Tertiary-aged clays. \\
\hline $\begin{array}{l}\text { Biotite-Black mica } \\
\mathrm{K}\left(\mathrm{MgFe}^{2+}\right)_{3} \mathrm{AlSi}_{3} \mathrm{O}_{10}(\mathrm{OH}, \mathrm{F})_{2}\end{array}$ & $\begin{array}{l}\text { Granitic rocks. Forms a series } \\
\text { with phlogopite. }\end{array}$ & Muscovite $\mathrm{KAl}_{2}\left(\mathrm{Si}_{3} \mathrm{Al}\right) \mathrm{O}_{10}(\mathrm{OH}, \mathrm{F})_{2}$ & Granites and pegmatites. \\
\hline Calcite $\mathrm{CaCo}_{3}$ & Found in all kind of rocks & $\begin{array}{l}\text { Nontronite } \\
\mathrm{Na}\left(\mathrm{Fe}^{3+}\right)_{2} \mathrm{Si}_{3} \mathrm{AlO}_{10}(\mathrm{OH})_{2} \cdot 4\left(\mathrm{H}_{2} \mathrm{O}\right)\end{array}$ & $\begin{array}{l}\text { It is the iron(III) rich } \\
\text { member of the smectite } \\
\text { group of clay meminerals. }\end{array}$ \\
\hline $\begin{array}{l}\text { Clinochlore } \\
\left(\mathrm{MgFe}^{2+}\right)_{5} \mathrm{Si}_{3} \mathrm{Al}_{2} \mathrm{O}_{10}(\mathrm{OH})_{8}\end{array}$ & $\begin{array}{l}\text { Alteration mineral. } \\
\text { Metamorphic rock. }\end{array}$ & $\begin{array}{l}\text { Pargasite } \\
\mathrm{NaCa}_{2} \mathrm{Mg}_{3}\left(\mathrm{Fe}^{2+}\right) \mathrm{Si}_{6} \mathrm{Al}_{3} \mathrm{O}_{22}(\mathrm{OH})_{2}\end{array}$ & $\begin{array}{l}\text { A complex inosilicate } \\
\text { mineral of the } \\
\text { amphibole group. }\end{array}$ \\
\hline $\begin{array}{l}\text { Diopside } \\
\mathrm{CaMg}\left(\mathrm{Si}_{2} \mathrm{O}_{6}\right)\end{array}$ & $\begin{array}{l}\text { Basic and ultrabasic igneous } \\
\text { and metamorphic rocks. }\end{array}$ & $\begin{array}{l}\text { Quartz } \\
\left(\mathrm{SiO}_{2}\right)\end{array}$ & $\begin{array}{l}\text { It is a component of almost } \\
\text { every rock type. }\end{array}$ \\
\hline $\begin{array}{l}\text { Ferroactinolite } \\
\mathrm{Ca}_{2}\left(\mathrm{Fe}^{2+}\right)_{5}\left(\mathrm{Si}_{8} \mathrm{O}_{22}\right)(\mathrm{OH})_{2}\end{array}$ & $\begin{array}{l}\text { Prismatic crystals of } \\
\text { ferro-actinolite } \\
\text { showing terminal crystal faces }\end{array}$ & $\begin{array}{l}\text { Riebeckite } \\
\mathrm{Na}_{2}\left(\mathrm{Fe}^{2+}\right)_{3}\left(\mathrm{Fe}^{3+}\right)_{2}\left(\mathrm{Si}_{8} \mathrm{O}_{22}\right)(\mathrm{OH})_{2}\end{array}$ & $\begin{array}{l}\text { A sodium-rich member of } \\
\text { the amphibole group } \\
\text { of silicate mine. }\end{array}$ \\
\hline $\begin{array}{l}\text { Fluorite } \\
\mathrm{CaF}_{2}\end{array}$ & Low temperature vein deposits. & $\begin{array}{l}\text { Saponite } \\
\left.\mathrm{CaNa}\left(\mathrm{MgFe}^{2+}\right)_{3} \mathrm{Si}_{3} \mathrm{AlO}_{10}(\mathrm{OH})_{2} \cdot 4 \mathrm{H}_{2} \mathrm{O}\right)\end{array}$ & $\begin{array}{l}\text { Amygdaloidal cavities } \\
\text { in basalts. }\end{array}$ \\
\hline $\begin{array}{l}\text { Gypsum } \\
\mathrm{Ca}\left(\mathrm{SO}_{4}\right) \cdot 2\left(\mathrm{H}_{2} \mathrm{O}\right)\end{array}$ & Sedimentary evaporite deposits & $\begin{array}{l}\text { Zaherite } \\
\mathrm{Al}_{12}\left(\mathrm{SO}_{4}\right)_{5}(\mathrm{OH})_{26} \cdot 20\left(\mathrm{H}_{2} \mathrm{O}\right)\end{array}$ & $\begin{array}{l}\text { In a massive } \\
\text { kaolinite-boehmite rock. }\end{array}$ \\
\hline $\begin{array}{l}\text { Kaolinite } \\
\mathrm{Al}_{2} \mathrm{Si}_{2} \mathrm{O}_{5}(\mathrm{OH})_{4}\end{array}$ & $\begin{array}{l}\text { Secondary mineral derived from } \\
\text { the weathering of } \\
\text { alumino-silicate minerals. }\end{array}$ & $\begin{array}{l}\text { Zircon } \\
\mathrm{ZrSiO}_{4}\end{array}$ & $\begin{array}{l}\text { Zircon is a mineral } \\
\text { (group of nesosilicates). }\end{array}$ \\
\hline $\begin{array}{l}\text { Magnetite } \\
\left(\mathrm{Fe}^{3+}\right)_{2}\left(\mathrm{Fe}^{2+}\right) \mathrm{O}_{4}\end{array}$ & $\begin{array}{l}\text { Common mineral in igneous, } \\
\text { metamorphic rocks, } \\
\text { known as lodestone }\end{array}$ & & \\
\hline
\end{tabular}

The mean concentrations of ${ }^{226} \mathrm{Ra},{ }^{232} \mathrm{Th}$ and ${ }^{40} \mathrm{~K}$ are greater than the mean values reported by UNSCEAR (Table 6). So, there is necessary need for more specific rules for buy and sale these local and imported housewares. Figure 1 shows the Activity concentrations (Bq/kg) of ${ }^{226} \mathrm{Ra},{ }^{232} \mathrm{Th}$ and ${ }^{40} \mathrm{~K}$.

A comparison between the results of activity concentrations for ${ }^{232} \mathrm{Th}$, and ${ }^{40}$ measured by $\gamma$-Ray spectrometer and concentrations values for Th, and $\mathrm{K}$ measured by A. A. Spectrometer. Both analysis results are in a good agreement and this means that the geochemical analysis (Atomic Absorption Spectrometer) can determine the concentrations of elements in the minerals with reasonable values, shown in Figure 2. 


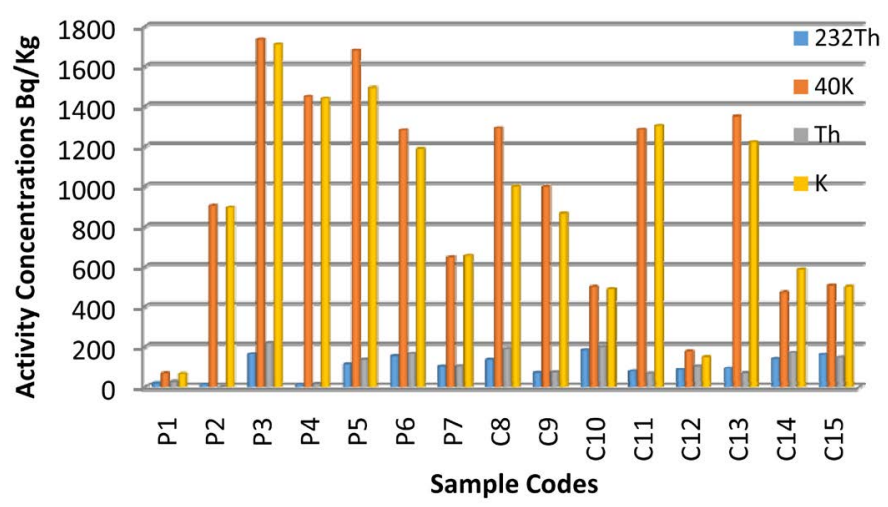

Figure 2. A comparison between activity concentrations for ${ }^{232} \mathrm{Th}$, and 40 measured by $\gamma$-Ray Spectrometer and concentrations values for Th, and K measured by A. A. Spectrometer.

Table 6. The specific activity concentrations in $\mathrm{Bq} / \mathrm{kg}$ for 15 samples.

\begin{tabular}{|c|c|c|c|}
\hline \multirow{2}{*}{ Sa. no. } & \multicolumn{3}{|c|}{ Specific activities $(\mathrm{Bq} / \mathrm{kg})$} \\
\hline & ${ }^{226} \mathrm{Ra}$ & ${ }^{232} \mathrm{Th}$ & ${ }^{40} \mathrm{~K}$ \\
\hline $\mathrm{P} 1$ & $22.26 \pm 0.01$ & $21.96 \pm 0.01$ & $67.10 \pm 0.01$ \\
\hline $\mathrm{P} 2$ & $11.51 \pm 0.04$ & $14.15 \pm 0.03$ & $904.37 \pm 0.02$ \\
\hline P3 & $184.68 \pm 0.04$ & $162.85 \pm 0.01$ & $1736.30 \pm 0.02$ \\
\hline $\mathrm{P} 4$ & $17.58 \pm 0.03$ & $13.01 \pm 0.02$ & $1449.60 \pm 0.02$ \\
\hline P5 & $108.35 \pm 0.03$ & $111.96 \pm 0.02$ & $1678.60 \pm 0.01$ \\
\hline P6 & $104.85 \pm 0.03$ & $153.16 \pm 0.01$ & $1280.08 \pm 0.02$ \\
\hline P7 & $192.67 \pm 0.05$ & $102.20 \pm 0.01$ & $648.53 \pm 0.01$ \\
\hline $\mathrm{C} 8$ & $76.80 \pm 0.05$ & $135.81 \pm 0.02$ & $1292.16 \pm 0.03$ \\
\hline C9 & $59.72 \pm 0.04$ & $68.86 \pm 0.01$ & $997.40 \pm 0.01$ \\
\hline $\mathrm{C} 10$ & $100.24 \pm 0.03$ & $184.04 \pm 0.02$ & $997.40 \pm 0.01$ \\
\hline $\mathrm{C} 11$ & $74.80 \pm 0.05$ & $76.98 \pm 0.01$ & $1284.55 \pm 0.02$ \\
\hline $\mathrm{C} 12$ & $59.03 \pm 0.06$ & $85.98 \pm 0.01$ & $177.55 \pm 0.02$ \\
\hline $\mathrm{C} 13$ & $81.22 \pm 0.05$ & $91.93 \pm 0.01$ & $1348.96 \pm 0.02$ \\
\hline $\mathrm{C} 14$ & $75.88 \pm 0.05$ & $140.26 \pm 0.01$ & $470.96 \pm 0.01$ \\
\hline $\mathrm{C} 15$ & $87.28 \pm 0.04$ & $160.10 \pm 0.02$ & $506.30 \pm 0.02$ \\
\hline Range & $11.51-192.67$ & $13.01-184.04$ & $67.10-1736.30$ \\
\hline Mean & 83.83 & 91.05 & 751.07 \\
\hline Worldwide ${ }^{*}$ & 35 & 30 & 400 \\
\hline
\end{tabular}

*UNSCEAR (2000).

\subsection{Radiation Hazard Indices}

The distribution of natural radionuclides in the samples is not the same. Therefore, radiological index has been used to estimate the actual activity values of ${ }^{226} \mathrm{Ra},{ }^{232} \mathrm{Th}$ and ${ }^{40} \mathrm{~K}$ in the samples and the radiation hazards accompanied with 
these radionuclides (the radium equivalent activity $R a_{e q}$, absorbed dose rate $D$, the annual effective dose rate $D_{\text {eff }}$ and external hazard index $H_{e x}$. The results were presented in (Table 7).

The values of the radium equivalent activities range in Porcelain from (58.83 to $551.25 \mathrm{~Bq} / \mathrm{kg}$ ). For Ceramic, the values of the radium equivalent activity range from $(195.66$ to $401.87 \mathrm{~Bq} / \mathrm{kg})$, its mean value for all samples is $(302.61 \mathrm{~Bq} / \mathrm{kg})$, which is lower than the worldwide value $(370 \mathrm{~Bq} / \mathrm{kg})$. The radium equivalent activities for samples (P: 3, 5, 6, 7 and C: 8, 10) are higher than the maximum admissible limit of $370 \mathrm{~Bq} / \mathrm{kg}$. The analysis of the data in Table 7 shows the variation of area for the same type of material. This is due to the place of origin, varied origin sources, different additives. More indices are useful to be found: gamma dose rate $D(\mathrm{nGy} / \mathrm{h})$, annual effective dose $D_{\text {eff }}(\mathrm{mSv} / \mathrm{year})$, and external hazard $H_{i x}$ for analyzed samples. The mean value of $D(\mathrm{nGy} / \mathrm{h})$ is 140.15 is higher than the maximum admissible limit of $60(\mathrm{nGy} / \mathrm{h}), D(\mathrm{nGy} / \mathrm{h})$ exceeding should be taken into account in terms of radiation protection. It is therefore recommended that controls should be based on a dose range. $D_{\text {eff }}(\mathrm{mSv} / \mathrm{year})$ and $H_{i x}$ are below the published admissible limit $\leq 1$ and the risk is negligible (UNSCEAR, 2000).

Table 7. $R a_{e q}(\mathrm{~Bq} / \mathrm{kg}), D(\mathrm{nGy} / \mathrm{h}), D_{e f f}(\mathrm{mSv} / \mathrm{year}), H_{i x}$

\begin{tabular}{|c|c|c|c|c|}
\hline Sa. no. & $R a_{e q}(\mathrm{~Bq} / \mathrm{kg})$ & $D(\mathrm{nGy} / \mathrm{h})$ & $D_{e f f}(\mathrm{mSv} /$ year $)$ & $H_{i x}$ \\
\hline $\mathrm{P} 1$ & 58.83 & 26.07 & 0.03 & 0.16 \\
\hline P2 & 101.38 & 52.62 & 0.07 & 0.27 \\
\hline P3 & 551.25 & 254.98 & 0.31 & 49 \\
\hline P4 & 147.80 & 77.94 & 0.10 & 0.40 \\
\hline P5 & 397.68 & 188.19 & 0.23 & 1.07 \\
\hline P6 & 422.43 & 195.23 & 0.24 & 1.14 \\
\hline P7 & 388.76 & 173.83 & 0.21 & 1.05 \\
\hline $\mathrm{C} 8$ & 370.21 & 172.84 & 0.21 & 1.00 \\
\hline $\mathrm{C} 9$ & 234.99 & 111.29 & 0.14 & 0.63 \\
\hline $\mathrm{C} 10$ & 401.87 & 178.94 & 0.22 & 1.09 \\
\hline C11 & 283.79 & 135.13 & 0.17 & 0.77 \\
\hline $\mathrm{C} 12$ & 195.66 & 86.41 & 0.11 & 0.53 \\
\hline $\mathrm{C} 13$ & 316.56 & 149.95 & 0.18 & 0.86 \\
\hline C14 & 312.72 & 140.04 & 0.17 & 0.85 \\
\hline C15 & 355.21 & 158.78 & 0.19 & 0.96 \\
\hline Mean & 302.61 & 140.15 & 0.17 & 0.82 \\
\hline Worldwide* & 370 & 60 & $\leq 1$ & $<1$ \\
\hline
\end{tabular}

*UNSCEAR (2000). 


\section{Conclusion}

Fifteen samples of ceramic and porcelain items commonly were found in everyday living in Jeddah Saudi Arabia were examined by three techniques. ${ }^{\star} \mathrm{X}$-ray diffraction provides detailed information about the atomic structure of crystalline substances, chemical composition and physical properties of materials. The major mineral constituent of all samples in ceramic (except P4) is quartz $\left(\mathrm{SiO}_{2}\right)$. Ceramic samples minor and trace elements vary from sample to sample. Porcelain is mostly kaolinite $\left(\mathrm{Al}_{2} \mathrm{Si}_{2} \mathrm{O}_{5}(\mathrm{OH})_{4}\right)$, and minor element is mullite $\left(\mathrm{Al}_{6} \mathrm{Si}_{2} \mathrm{O}_{13}\right)$ (except P7), its minor element is Albite $\left(\mathrm{NaAlSi}_{3} \mathrm{O}_{8}\right)$. This is due to the geological origin for the samples. Atomic absorption spectroscopy is used to measure the concentration values in ppm for sex elements $(\mathrm{Al}, \mathrm{Pb}, \mathrm{Bi}, \mathrm{U}, \mathrm{Th}, \mathrm{K})$. In this study, ceramic and porcelain include Aluminum (Al) which is known to be toxic to different species, the mean concentration ( $\mathrm{ppm}$ ) of $\mathrm{Al}$ is $10.3 \mathrm{ppm}$ which is less than the acceptable value. Toxicity lead oxide $(\mathrm{PbO})$ glazes are used on many kinds of porcelain and ceramic food wares. The allowed limit is $0.2 \mathrm{ppm}$ (EC, 2005), the mean concentration value is $1.65 \mathrm{ppm}$. Bi concentrations for all samples were lower than $(\mathrm{DL}<10)$. For $\mathrm{U}$, concentrations were lower than (DL $<5)$ except two samples, Thorium is chemotoxic, radiotoxic and a carcinogen element. The mean concentration value is $27.16 \mathrm{ppm}$, which is much greater than the acceptable value $7.24 \mathrm{ppm}$. Potassium is the eighth most abundant element in the Earth's crust (2.1\%), Potassium mean concentration is 24974.54 ppm (2.5\%), which is greater than the acceptable value (1.92\%). ${ }^{\star}$ Porcelain and ceramic samples were measured using the gamma spectrometer. The results show that: their activities were used to calculate the concentrations of ${ }^{226} \mathrm{Ra}$, Th and ${ }^{40} \mathrm{~K}$. The mean concentrations of ${ }^{226} \mathrm{Ra},{ }^{232} \mathrm{Th}$ and ${ }^{40} \mathrm{~K}$ are greater than the mean values reported by UNSCEAR. So, there is necessary need for more specific rules for buy and sale these local and imported housewares. The mean value of the radium equivalent activities for all samples is $(302.61 \mathrm{~Bq} / \mathrm{kg})$, which is lower than the worldwide value $(370 \mathrm{~Bq} / \mathrm{kg})$. This is due to the place of origin, varied origin sources, different additives. Indices mean values of $D(\mathrm{nGy} / \mathrm{h}), D_{\text {eff }}$ (mSv/year) and $H_{i x}$ are useful to be found in terms of radiation protection. The mean value of $D(\mathrm{nGy} / \mathrm{h})$ is higher than the maximum admissible limit. It is therefore recommended that controls should be based on a dose range. $D_{\text {eff }}$ (mSv/year) and $H_{i x}$ are below the published admissible limit $\leq 1$ and the risk is negligible.

\section{Acknowledgements}

The author is appreciated to the Saudi Geological Survey (SGS) for their technical help.

\section{Conflicts of Interest}

The author declares no conflicts of interest regarding the publication of this paper. 


\section{References}

Abbady, A. G. E. (2004). Estimation of Radiation Hazard Indices from Sedimentary Rocks in Upper Egypt. Applied Radiation and Isotopes, 60, 111-114. https://doi.org/10.1016/j.apradiso.2003.09.012

Ahmad, N., Jaafar, M., \& Alsaffar, M. (2015). Natural Radioactivity in Virgin and Agricultural Soil and Its Environmental Implications in Sungai Petani, Kedah, Malaysia. Pollution, 1, 305-313.

Aksoy et al. (2010). Natural Radioactivity in Selected Clay, Ceramic and Granite Household Items. Journal of International Environmental Application \& Science, 5, 167-171.

Almayahi, B., Tajuddin, A., \& Jaafer, M. (2012). Radiation Hazard Indices of Soil and Water Samples in Northern Malaysian Peninsula. Applied Radiation and Isotopes, 70, 2652-2660. https://doi.org/10.1016/j.apradiso.2012.07.021

Don Leet, L., Sheldon, J., \& Kauffman, M. (1982). Physical Geology (6th ed.). Englewood Cliffs, NJ: Prentice-Hall.

EC (2005). Community. Commission Regulation No. 78/2005. Official Journal of the European Union, L16/43-L16/45.

El Aassy Ibrahim, E. et al. (2011). Effect of Alteration Processes on the Distribution of Radionuclides in Uraniferous Sedimentary Rocks and Their Environmental Impact Southwestern Sinai, Egypt. Journal of Radioanalytical and Nuclear Chemistry, 289, 173-184. https://doi.org/10.1007/s10967-011-1059-1

Emsley, J. (2001). Nature's Building Blocks: An A-Z Guide to the Elements. Oxford: Oxford University Press.

Harris, W., \& White, G. N. (2008). X-Ray Diffraction Techniques for Soil Mineral Identification. In A. L. Ulery, \& L. R. Drees (Eds.), Methods of Soil Analysis, Part 5. Mineralogical Analysis (p. 677). Wisconsin: American Society of Agronomy.

Heiserman, D. L. (1992). Exploring Chemical Elements and Their Compounds. New York: TAB Books.

Janković, M. M. et al. (2013). Natural Radioactivity in Imported Ceramic Tiles Used in Serbia. Processing and Application of Ceramics, 7, 123-127. https://doi.org/10.2298/PAC1303123J

Lehman, R. L. (2002). Lead Glazes for Ceramic Food Ware (pp. 1, 2). North Carolina: The International Lead Management Center, USA.

Mineral Data (2012). Webmineral.com.

Papadopoulos et al. (2013). Natural Radioactivity and Radiation Index of the Major Plutonic Bodies in Greece. Journal of Environmental Radioactivity, 124, 227-238. https://doi.org/10.1016/j.jenvrad.2013.06.002

Rudnick, R. L. et al. (2004). Recycling Lower Continental Crust in the North China Craton. Nature, 432, 892-897. https://doi.org/10.1038/nature03162

Tufail, M. et al. (2010). Assessment of Annual Effective Dose from Natural Radioactivity Intake through Heat Grain Produced in Faisalabad, Pakistan. Journal of Radioanalytical and Nuclear Chemistry, 283, 585-590. https://doi.org/10.1007/s10967-009-0391-1

UNSCEAR (1993). United Nations Scientific Committee on the Effects of Atomic Radiation. Sources an Effects of Ionizing Radiations. New York: United Nations.

UNSCEAR (2000). Sources and Effects of Ionizing Radiation. New York: United Nations Scientific Committee on the Effects of Atomic Radiation, Vol. I, UN Report to the General Assembly.

Veiga, R. et al. (2006). Measurement of Natural Radioactivity in Brazilian Beach Sands. Radiation Measurements, 41, 189-196. https://doi.org/10.1016/j.radmeas.2005.05.001 
Younis, H., Qureshi, A. A., Manzoor, S., \& Anees, M. (2018). Measurement of Radioactivity in the Granites of Pakistan: A Review. Health Physics, 115, 760-768.

https://doi.org/10.1097/HP.0000000000000917 